\title{
Cadmium Causes Increases of N-myc and Multidrug-resistance Gene mRNA in Neuroblastoma Cells
}

\author{
Tadamasa MURAKami, Hisamitsu OHMORI, Takahiko KaTOH, \\ Tetsuya ABE and Ken HIGASHI \\ Department of Biochemistry, School of Medicine, University of Occupational and Environmental Health, \\ Japan. Kitakyushu 807, Japan
}

Abstract: $\quad$ Since cadmium exposure results in neuropathological alterations in central nervous system, we investigated the effects of cadmium on the gene expression of neuroblastoma (GOTO) cells. We observed an increase in mRNA levels of heat-shock protein (hsp) 70, hsp 90, hsp 32 and metallothionein after treatment of GOTO cells with cadmium, although the time courses of the changes of individual mRNA of the heat-shock proteins and metallothionein were somewhat different from each other. An accumulation of N-myc and multidrug-resistance gene (MDRl) mRNA was detected in the presence of cadmium. This is contrary to the previous report, in which an inverse correlation between the expression of MDRl gene and N-myc oncogene in human neuroblastoma had been described. However, the increase of N-myc and MDR 1 mRNA in the present study is not likely due to the loss of regulatory mechanism of these genes by cytotoxic effects of cadmium, because active protective mechanisms such as heat-shock proteins and metallothionein could be induced under these conditions.

Key words: cadmium, metallothionein, heat-shock protein, N-myc, multidrug-resistance gene.

(Received 15 August 1991, accepted 11 October 1991)

\section{Introduction}

Cadmium is an ubiquitous heavy metal toxicant found throughout the industrial world and accumulating in the environment. Occupational exposure to cadmium may cause kidney, lung and prostate cancers (Sunderman, 1977; Hallenbeck, 1984). The carcinogenic activity of cadmium compounds has been reported by many investigators. Cadmium has been reported to induce chromosomal aberrations (Ochi et al., 1984), transform cultured cells and also to enhance viral transformation (Terracido \& Nachtigel, 1986; Casto et al., 1979). On the other hand, cadmium exposure results in neuropathological changes in the central nervous system (Gulati et al., 1986) as well as behavioral changes such as increased hyperactivity and irritability in animals (Rastogi et al., 1977).

The biochemical influence with cadmium is, however, not fully understood at the present time. Recently, Smith et al. (1989) have shown that cadmium evoked inositol polyphosphate formation and calcium mobilization in human skin fibroblasts. Cellular $\mathrm{Ca}^{2+}$ mobilization may promote cell growth (Rosengurt, 1986) and account in part for the carcinogenicity of the metals (Smith et al., 1989; Miller, 1987). Cadmium induced c-jun 
and c-myc mRNA in a concentration dependent manner (Jin \& Ringertz, 1990). On the other hand, cadmiun induces increased transcriptions of heat-shock protein genes (Misra $e t$ al., 1989), metallothionein gene (Karin et al., 1984) and heme oxygenase gene (Alam et al., 1989). Since cadmium promotes lipid peroxidation (Anderson, H. \& Anderson, O., 1988; Solé et al., 1990) in the cell membrane and this evidently contributes to the toxicity of cadmium in the central nervous system, we examined the effects of cadmium on the gene expression in neuroblastoma cells.

\section{Material and Method}

Cell Culture: GOTO cells were obtained from the Japanese Cancer Research Resources Bank (Tokyo) and grown in RPMI 1640 supplemented with glutamine $(2 \mathrm{mM})$, penicillin (50 u$\mathrm{nit} / \mathrm{ml}$ ), streptomycin $(50 \mu \mathrm{g} / \mathrm{ml})$, and 10\% fetal calf serum (Gibco Lab., NY) in a humidified atmosphere of $95 \%$ air and $5 \% \mathrm{CO}_{2}$. Cells were plated at $5 \times 10^{5} \mathrm{cells} / \mathrm{ml} / \mathrm{cm}^{2}$. After a $24 \mathrm{~h}$ subculture, cells were maintained in RPMI 1640 containing 10\% FCS and either with or without an addition of $\mathrm{CdCl}_{2}$ at a final concentration of $10 \mu \mathrm{M}$ for a given period.

RNA extraction and Northern Blots: Total cellular RNA was isolated from neuroblastoma cells by using the guanidinium thiocyanate procedure (Chirgwin et al., 1979). Twenty micrograms of total RNA was electrophoresed on $1 \%$ agarose (SeaKem, ME) under denaturing conditions (Lehrach et al., 1977) and transferred to nylon filters (Hybond N, Amersham, U. K.). The filters were hybridized with ${ }^{32}$ P-labeled nick-translated probes. Hsp 70 [human, BamHI fragment, 0.8kb (Kao \& Nevins, 1983)], hsp90 [human, PstI fragment, 1.4kb (Hickey et al., 1986)], hsp32 [rat, EcoRI Fragment, 1.5kb (Kageyama et al., 1988)], N-myc [human, EcoRI-BamHI fragment, 1.0kb (Kohl et al., 1986)], mdr-l [human, EcoRI fragment, 1.5kb (Roninson et al., 1986)], were used as the probes. Hybridization and washing of filters were carried out as described previously (Murakami et al., 1991b). Quantitation of mRNA was carried out with a Bioimage-Analyzer (BAS 2000, Fujix, Tokyo).

\section{Results}

First of all, the induction of metallothionein and several heat-shock genes after treatment of neuroblastoma (GOTO) cells with cadmium was studied. The levels of metallothionein mRNA began to increase at $2 \mathrm{~h}$ after treatment and gradually increased until $15 \mathrm{~h}$ (Fig. 1 ). On the contrary, transcriptions of heat-shock proteins, that is, hsp70, hsp90 and hsp32 (heme oxygenase) were stimulated at $2 \mathrm{~h}$ and peaked at $6 \mathrm{~h}$ and then declined (Fig. 1). The induction of hsp70 was transient, but those of hsp90 and hsp32 were maintained for longer period than that of hsp70. It is unknown whether these different time courses of individual heat-shock protein genes are due to differences of transcriptional activity or halflives of individual gene products. As far as we know, this is the first demonstration of the 


\section{$02615 \mathrm{hr}$ $-h \operatorname{hsp} 70$ \\ $-4 h \operatorname{hsp} 32$ \\ $-\infty \omega$ hsp9o \\ $-0 \mathrm{MT}$

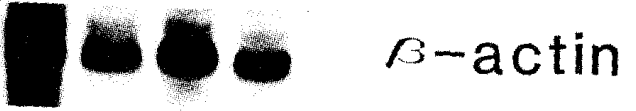

Fig. 1. Time course of the levels of heat-shock protein and metallothionein (MT) mRNA after cadmium treatment. RNA was prepared at the time indicated, electrophoresed on $1 \%$ agarose and transferred on nylon filters as described in Material and Methods. The levels of individual heat-shock proteins (hsp70, hsp32, hsp90) and metallothionein (MT) mRNAs were determined after hybridization of these filters with individual ${ }^{32} \mathrm{P}$-labeled probes (see Materials and Methods).

\section{$02615 \mathrm{hr}$ $-N$-myc}



Fig. 2. Changes of $N$-myc and multidrug-resistance gene (MDR) mRNA levels after treatment of GOTO cells with cadmium. Northern-blot analysis of N-myc and MDR was carried out as described in the legend to Fig. 1. 
induction of hsp90 after cadmium treatment.

Next, we analyzed N-myc gene expression, which is constitutively expressed in GOTO cells, after treatment of these cells with cadmium. Interestingly, $\mathrm{N}$-myc mRNA levels increased in the presence of cadmium and showed a threefold content of control cells at $6 \mathrm{~h}$. After this time point, N-myc mRNA decreased gradually and returned to the control levels at $15 \mathrm{~h}$ (Fig. 2).

The effect of cadmium compounds has been studied in many cell culture systems, particularly in relation to development of cadmium-resistant cell populations. The increase of metallothionein synthesis was mostly associated with an amplification of metallothionein genes (Beach \& Palmitter, 1981; Gick \& McCarty, 1982). Another possible mechanism to develop resistant cells to some compounds is the induction of multi-drug resistance genes, which might be a serious problem of chemotherapy in neuroblastoma. We examined the behavior of MDR1 mRNA content after the addition of cadmium into the culture medium, and observed the peak of MDRl mRNA at $6 \mathrm{~h}$ after cadmium treatment (Fig. 2).

\section{Discussion}

Cadmium has been recognized as an environmental pollutant for many years and is found to be toxic to some extent to almost every organ studied. Several studies have shown that cadmium exposure results in neuropathological and neurochemical alterations in the central nervous system (Gabbiani et al., 1967; Gulati et al., 1986). Since divalent ions of transition metals can promote lipid peroxidaiton and the brain contains high amounts of polyunsaturated fatty acids, the cell membrane of the central nervous system might be a primary target for toxic metals (Gill et al., 1989). In the present study, we examined the effects of cadmium on the gene expression in neuroblastoma GOTO cells as a model system to see the defensive response to toxic metal and to search out any genes affected by this metal.

The results reported in this paper demonstrated that cadmium induced simultaneous accumulation of $\mathrm{N}$-myc, several heat-shock protein genes, and metallothionein mRNAs.

Although the induction of metallothionein and heat-shock proteins after cadmim treatment is useful to protect cells from cytotoxic action of this metal, at least a part of the changes of heat-shock proteins might contribute to other cellular functions (Kingston et al., 1984; Pelham, 1986; Milarski \& Morimoto, 1986; Welch, 1986; Ohmori et al., 1990; Murakami et al., 1991a, b). Cadmium has been reported to induce transcription of protooncogene c-myc in rat myoblasts (Jin \& Ringertz, 1990). We found the accumulation of Nmyc mRNA in neuroblastoma cells after cadmium treatment, although it is unknown how the induction of the myc family participates in the pathogenesis of nervous cells.

Induction of metallothionein was suggested as the mechanism of protection for cadmium toxicity. Furthermore, cadmium-resistant cells have been isolated in many established cell lines. The mechanism of resistance has been attributed to the synthesis of 
metallothionein by the cadmium-exposed mutant (Beach \& Palmiter, 1981; Gick \& McCarty, 1982). On the other hand, Chin et al. (1990) have reported that exposure of HTB-46 cells to cadmium chloride led to a 7-to 8-fold increase in MDR1 mRNA. MDRl gene product, a multidrug transporter, was initially identified as a multidrug efflux pump responsible for cultured cells to natural product toxic drugs (Fojo et al., 1985; Riorden et al., 1985). In the neuroblastoma cells, there was a 3-fold increase of MDRI mRNA after cadmium treatment (Fig. 2). However, the MDRl gene product probably does not play a direct role in conferring resistance to heavy metals because some multidrug-resistant cells did not show increased resistance to $\mathrm{CdCl}_{2}$ (Chin et al., 1990).

The development of resistance to chemotherapy in neuroblastoma is a serious problem. Previously, however, Nakagawara et al. (1990) reported an inverse correlation between expression of MDR genes and N-myc oncogene in neuroblastoma-samples obtained from the primary tumors of patients at the surgical operation. An increase at the levels of MDR1 mRNA was also observed after retinoic acid treatment of neuroblastoma cell lines (Bates et al., 1989). These results suggest that the expression of the MDR gene might be associated with less malignant cases of neuroblastoma and also with the differentiated state of neuroblastoma cells having lower levels of $\mathrm{N}$-myc expression. On the contrary, simultaneous increase of both N-myc and MDRl mRNA was observed in the present study after cadmium treatment. However, the increase of N-myc and MDRl mRNA is not likely a consequence of merely the loss of the regulatory mechanism of these genes by cytotoxic effects of cadmium, since active induction of mRNA for defensive mechanism such as metallothionein and heat-shock proteins could occur under these conditions. Further study on the relationship between $\mathrm{N}$-myc, heat-shock proteins and lipid peroxidation by cadmium is under way in our laboratory.

\section{Acknowledgments}

We are grateful to Drs. Joseph R. Nevins, Lee A. Weber, Shigeru Sakiyama, Nancy E. Kohl, and Michael Gottesman for providing the probes employed in this study, and to the Japanese Cancer Research Resources Bank for providing the neuroblastoma GOTO cells. We also want to thank Miss Mika Kawabata for her technical assistance and preparing the manuscript.

This work was supported in part by Grants-in-Aid from the Ministry of Education, Science and Culture of Japan and by a special grant for Occupational Health Studies from the Ministry of Labor of Japan.

\section{References}

Alam, J., Shibahara, S. \& Smith, A. (1989): Transcriptional activation of the heme oxygenase gene by heme and cadmium in mouse hepatoma cells. J. Biol. Chem., 264: 6371-6375.

Anderson, H. R., \& Anderson, O. (1988): Effect of cadmium on hepatic lipid peroxidation in mice. 
Pharmacol. Toxicol., 63: 173-177.

Bates, S. E., Mickley, L. A., Chen, Y. et al. (1989): Expression of a drug resistance gene in human neuroblastoma cell lines: Modulation by retinoic acid-induced differentiation. Mol. Cell. Biol., 9: 43374344.

Beach, L. R. \& Palmiter, R. D. (1981): Amplification of the metallothioneion- I gene in cadmium-resistant mouse cells. Proc. Natl. Acad. Sci. USA., 78: 2110-2114.

Cast, B. C., Meyers, J. \& DiPaolo, J. A. (1979): Enhancement of viral transformation for evaluation of the carcinogenic or mutagenic potential of inorganic metal salts. Cancer Res., 39: 193-198.

Chin, K-V., Tanaka, S., Darlington, G. et al. (1990): Heat shock and arsenite increase expression of the multidrug resistance (MDRl) gene in human renal carcinoma cells. J. Biol. Chem., 265: 221-226.

Chirgwin, J. M., Przybyla, A. E., MacDonald, R. J. et al. (1979): Isolation of biologically active ribonucleic acid from sources enriched in ribonuclease. Biochemistry, 18: 5294-5299.

Fojo, A. T., Akiyama, S. I., Gottesman, M. M. et al. (1985): Reduced drug accumulation in multiple drug resistant human KB carcinoma cell lines. Cancer Res., 45: 3002-3007.

Gabbiani, G., Baic, D. \& Dezeil, C. (1967): Toxicity of cadmium for the central nervous system. Exp. Neurol., 18: 154-160.

Gick, G. G. \& McCarty, K. S. (1982): Amplification of the metallothionein- I gene in cadmium- and zincresistant Chinese hamster ovary cells. J. Biol. Chem., 257: 9049-9053.

Gill, K. D., Pal, R. \& Nath, R. (1989): Effect of cadmium on lipid peroxidation and antioxidant enzymes in undernourished weanling rat brain. Pharmacol. Toxicol., 65: 73-77.

Gulati, S., Gill, K. D. \& Nath, R. (1986): Effect of cadmium on the lipid composition of weanling rat brain. Acta Pharmacol. Toxicol., 59: 89-93.

Hallenbeck, W. H. (1984): Human health effects of exposure to cadmium. Experientia, 40: 136-142.

Hickey, E., Brandon, S. E., Sadis, S. et al. (1986): Molecular cloning of sequences encoding the human heatshock proteins and their expression during hyperthermia. Genc, 43: 147-154.

Jin, P. \& Ringertz, N. R. (1990): Cadmium induces transcription of protooncogenes c-jun and c-myc in rat L6 myoblasts. J. Biol. Chem., 265: 14061-14064.

Kageyama, H., Hiwasa, T., Tokunaga, K. et al. (1988): Isolation and characterization of a complementary DNA clone for a Mr 32,000 protein which is induced with tumor promotors in BALB/C 3T3 cells. Cancer Res., 48: 4795-4798.

Kao, H. T. \& Nevins, J. R. (1983): Transcriptional activation and subsequent control of the human heat shock gene during adenovirus infection. Mol. Cell. Biol., 3: 2058-2065.

Karin, M., Haslinger, A., Holtgreve, H. et al. (1984): Characterization of DNA sequences through which cadmium and glucocorticoid hormones induce human metallothionein- II gene. Nature, 308: 513519.

Kingston, R. E., Baldwin, Jr. A. S. \& Sharp, P. A. (1984): Regulation of heat shock protein 70 gene expression by c-myc. Nature, 312: 280-282.

Kohl, N. E., Legouy, E., Depinho, R. A. et al. (1986): Human N-myc is closely related in organization and nucleotide sequence to c-myc. Nature, 319: 73-77.

Lehrach, H., Diamond, D., Wozney, J. M. et al. (1977): RNA molecular weight determinations by gel electrophoresis under denaturing conditions, a critical reexamination. Biochemistry, 16: 4743-4751.

Milarski, K. \& Morimoto, R. I. (1986): Expression of human HSP70 during the synthetic phase of the cell cycle. Proc. Natl. Acad. Sci. USA., 83: 9517-9521.

Miller, R. J. (1987): Multiple calcium channels and neuronal function. Science, 235: 46-52.

Misra, S., Zafarullah, M., Prince-Haughey, J. et al. (1989): Analysis of stress induced gene expression in fish cell lines exposed to heavy metals and heat shock. Biochim. Biophys. Acta, 1007: 325-333.

Murakami, T., Ohmori, H., Gotoh, S. et al. (1991a): Down modulation of N-myc, heat-shock protein 70, and nucleolin during the differentiation of human neuroblastoma cells. J. Biochem., 110: 146-150.

Murakami, T., Ohmori, H., Tsuda, T. et al. (199lb): The effect of changes of N-myc products on the gene 
expression of heat-shock protein (hsp70) and nucleolin during differentiation of neuroblastoma cells. In: Advance in Neuroblastoma Research. Vol. 3. (Evans, A. E. et al., ed.). Willey Liss. Inc., N. Y. pp. $65-70$.

Nakagawara, A., Kadomatsu, K., Sato, S. el al. (1990): Inverse correlation between expression of multidrug resistance gene and N-myc oncogene in human neuroblastomas. Cancer Res., 50: 3043-3047.

Ochi, T., Mogi, M., Watanabe, M. et al. (1984): Induction of chromosomal aberrations in cultured Chinese hamster cells by short-term treatment with cadmium chloride. Mutat. Res., 137: 103-109.

Ohmori, H., Murakami, T., Furutani, A. et al. (1990): Simultaneous activation of heat shock protein (hsp70) and nucleolin genes during in vivo and in vitro prereplicative stages of rat hepatocytes. Exp. Cell Res., 189: 227-232.

Pelham, H. R. B. (1986): Speculations on the functions of the major heat shock and glucose regulated proteins. Gell, 46: 959-961.

Rastogi, R. B., Merale, Z. \& Singhal, R. L. (1977): Cadmium alters behaviour and biosynthetic capacity for catecholamines and serotonin in neonatal rat brain. J. Neurochem., 28: 789-794.

Riordan, J. R., Deuchars, K., Kartner, N. et al. (1985): Amplification of P-glycoprotein genes in multidrugresistant mammalian cell lines. Nature, 316: 816-819.

Roninson, I. B., Chin, J. E., Choi, K. et al. (1986): Isolation of human $m d r$ DNA sequences amplified in multidrug-resistant KB carcinoma cells. Proc. Natl. Acad. Sci. USA., 83: 4538-4542.

Rozengurt, E. (1986): Early signals in the mitogenic response. Science, 234: 161-166.

Smith, J. B., Dwyer, S. D. \& Smith, L. (1989): Cadmium evokes inositol polyphosphate formation and calcium mobilization. Evidence for a cell surface receptor that cadmium stimulates and zinc antagonizes. J. Biol. Chem., 264: 7115-7118.

Solé, J., Huguet, J., Arola, L. et al. (1990): In vivo effects of nickel and cadmium in rats on lipid peroxidation and ceruloplasmin activity. Bull. Environ. Contam. Toxicol., 44: 686-691.

Sunderman, F. W. Jr. (1977): Metal Carcinogenesis. In: Advanes in Modern Toxicology. Vol. 1. (Goyer, R. A. \& Mchlamm, M. A., ed.). Hemisphere Publishing Co., Washington, D. C. pp. 257295.

Terracio, L. \& Nachtigal, M. (1986): Transformation of prostatic epithelial cells and fibroblasts with cadmium chloride in vitro. Arch. Toxicol., 58: 141-151.

Welch, W. J. (1986): Cellular and biochemical events in mammalian cells during and after recovery from physiological stress. J. Cell Biol., 103: 2035-2053. 
カドミウム処理による神経芽細胞腫培養細胞の N-myc および MDR (多薬剂耐性遺伝子) の mRNA 量の増加

村上 忠正 · 大森 久光·加藤 貴彦・安部 哲哉・東 監 锖業医科大学生化学教室

要旨：カドミウムは，発癌性を示すばかりでなく，中枢神経系に病変を起こすことも報告されて いる．神経芽細胞種由来の培養細胞であるGOTO 細胞にカドミウム処理をし遺伝子発現 への影響をみた．カドミウム投与後，メタロチオネイン，hsp70,hsp90，およびhsp32 mRNA の増量がみられ，熱ショック蛋白質の mRNA は，6時間でピークを示したが，メ タロチオネインの mRNA は，さらに15時間まで增え続けた。これらの条件下で N-myc とMDR1 (多薬戍涌性遺伝子) の mRNA も增量し約 6 時間でピークがみられた。メロ チオネインや熱ショック蛋白質の活発な誘導パターンからみて N-myc や MDR1の mRNA の増量は単にカドミウムによる細胞毒性のため,これらの遺伝子の抑制機構が脱落したた めとは考えられない。

J. UOEH (産業医大誌), $13(4): 271-278$ (1991) 